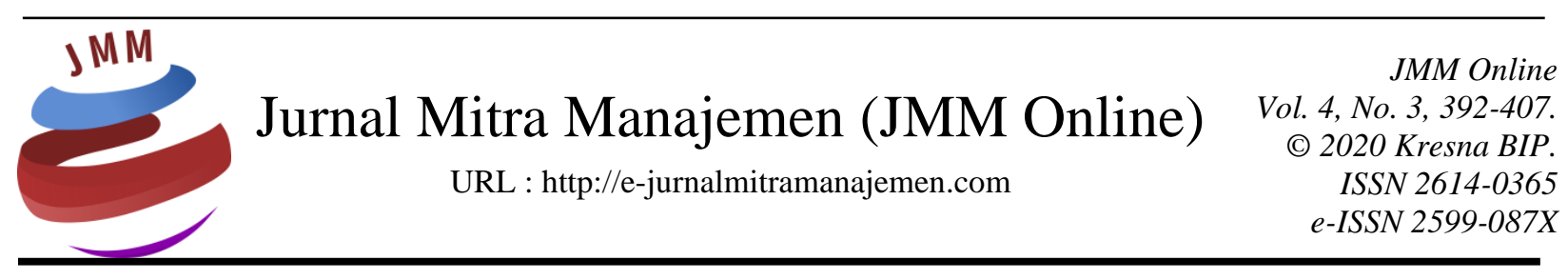

\title{
PENGARUH ORIENTASI KEWIRAUSAHAAN DAN INOVASI PRODUK TERHADAP KINERJA USAHA KECIL MENENGAH DENGAN VARIABEL INTERVENING KEUNGGULAN BERSAING (STUDI PADA UKM DI BANJARMASIN)
}

\author{
Isra Ul Huda ${ }^{1)}$, Anthonius J. Karsudjono ${ }^{2)}$, Pupita Nia Maharani ${ }^{3)}$ \\ Sekolah Tinggi Ilmu Ekonomi Pancasetia Banjarmasin
}

INFORMASI ARTIKEL

Dikirim : 09 Maret 2020

Revisi pertama : 26 Maret 2020

Diterima : 27 Maret 2020

Tersedia online : 30 Maret 2020

Kata Kunci: Orientasi Kewirausahaan, Inovasi Produk, Kinerja Usaha, Keunggulan Bersaing

Email : israulhuda@yahoo.com ${ }^{1)}$, tonimbbm@yahoo.com ${ }^{2)}$, dedewulan4x@gmail.com ${ }^{3)}$
ABSTRAK

Penelitian ini bertujuan untuk mengetahui dan menganalisa pengaruh Orientasi Kewirausahaan dan Inovasi Produk Terhadap Kinerja Usaha Kecil Menengah dengan Variabel Intervening Keunggulan Bersaing. Penelitian ini menggunakan metode analisa data kuantitatif, teknik analisis adalah Partial Least Square (PLS). Alasan pemilihan menggunakan metode PLS ini adalah adanya pengujian peran mediasi suatu variabel intervening. Hasil analisis yang dilakukan menyatakan bahwa Orientasi Kewirausahaan tidak berpengaruh signifikan terhadap Keunggulan Bersaing dan juga Kinerja Usaha Kecil Menengah. Inovasi Produk berpengaruh signifikan terhadap Keunggulan Bersaing dan tidak berpengaruh signifikan terhadapKinerja Usaha Kecil Menengah dan Keunggulan Bersaing tidak berpengaruh signifikan terhadap Kinerja Usaha Kecil Menengah. Orientasi Kewirausahaan tidak berpengaruh signifikan Terhadap Kinerja Usaha Kecil Menengah dengan Variabel Intervening Keunggulan Bersaing dan Inovasi Produk tidak berpengaruh signifikan Terhadap Kinerja Usaha Kecil Menengah dengan Variabel Intervening Keunggulan Bersaing. 


\section{PENDAHULUAN \\ Latar Belakang}

Pada setiap negara berkembang salah satu hal yang menjadi prioritas utama dalam melaksanakan kegiatan negaranya yaitu pembangunan nasional, begitu pula halnya dengan Indonesia, salah satu hal yang diperhatikan dalam pembangunan nasional di Indonesia adalah di bidang ekonomi. Untuk mewujudkan pembangunan nasional di bidang ekonomi bukan hanya menjadi tanggungjawab dari pemerintah pusat tetapi juga tanggungjawab dari pemerintah daerah. Dengan adanya Undangundang Nomor 32 Tahun 2004 tentang pemerintahan daerah yang mempunyai wewenangan luas dalam membangun potensi daerahnya. Salah satu yang menjadi potensi ditiap daerah adalah keberadaan Usaha Kecil Menengah (UKM).

Usaha Kecil dan Menengah (UKM) memiliki peranan yang sangat penting dalam perekonomian Nasional. Peranan penting ini terutama ditunjukkan dalam aspekaspek seperti peningkatan kesempatan kerja, pemerataan pendapatan, berperan dalam menekan laju urbanisasi dan pemeratan pembangunan ekonomi pedesaan. Sektor UKM pada kenyataannya mampu menunjukkan kinerja yang lebih tangguh dalam menghadapi masa-masa kritis pada saat terjadinya krisis ekonomi. UKM cukup fleksibel dan dapat dengan mudah beradaptasi dengan pasang surut dan arah permintaan pasar. Mereka juga menciptakan lapangan pekerjaan lebih cepat dibandingkan sektor usaha lainnya, dan mereka juga cukup terdiversifikasi dan memberikan kontribusi penting dalam ekspor dan perdagangan (Kanaidi, 2014: 101).

Kinerja UKM menjadi penting untuk dibicarakan karena menyangkut keberadaan dan keberlangsungan usahanya dimasa yang akan datang. Tanpa adanya kinerja usaha, maka UKM yang selama ini dijalankan berarti dianggap tidak mampu memberikan kontribusi yang menguntungkan bagi pengelola dan orang lain yang ikut terlibat didalammya. Kinerja usaha selama ini masih sering diabaikan oleh pelaku UKM, padahal untuk bisa mengetahui sejauh mana keberhasilan dalam melaksanakan kegiatannya harus diketahui bagaimana kegiatan tersebut dilaksanakan. Hal ini disebabkan seringnya pelaku UKM buka dan tutup usaha, berganti usaha yang dilakukan karena mengalami kerugian ataupun kurang diminati atau bahkan kalah bersaing dengan pengusaha yang lebih besar, serta kemampuan dalam pengelolaan usaha yang mendasar belum dimiliki oleh para pelaku usaha. Beberapa masalah itu sebenarnya yang akan mempengaruhi keberhasilan usaha yang dilakukan, namun dengan adanya manajerial yang bagus dan keinginan untuk melakukan inovasi diharapkan masalah tersebut dapat diatasi (Suswanto, 2011:84).

Terdapat beberapa faktor yang dapat mempengaruhi kinerja usaha kecil menengah dikemukakan oleh (Rita Indah Mustikowati dan Reni Shinta Dewi, 2014) diantaranya orientasi kewirausahaan, inovasi, strategi bisnis, manajemen sumber daya manusia, karakteristik wirausahawan dan karakteristik dari usaha itu sendiri. Namun dalam penelitian ini peneliti menggabungkan variabel orientasi kewirausahaan dan inovasi produk untuk mengetahui pengaruhnya terhadap kinerja usaha kecil menengah dan juga keunggulan bersaing.

Orientasi kewirausahaan diidentifikasikan sebagai salah satu faktor yang mempengaruhi kinerja usaha. (Prieto, 2010) orientasi kewirausahaan seorang pengusaha dianggap memilki peranan yang signifikan dalam kesuksesan suatu bisnis, 
sehingga bisnis tersebut dapat berkinerja dengan sehat. (Rauch dkk, 2009) menyatakan orientasi kewirausahaan dipandang memiliki kemampuan untuk meningkatkan kinerja sebuah perusahaan. Orientasi kewirausahaan merupakan komponen yang sangat penting dalam mengembangkan usaha, hal tersebut terlihat dari pemilik dan pengelola dalam menjalankan usahanya sudah menunjukkan perilaku inovatif, proaktif dan berani dalam mengambil resiko.

Inovasi juga diidentifikasikan sebagai salah satu faktor yang mempengaruhi kinerja usaha. Beberapa penilitian mengungkapkan hal tersebut seperti penelitian yang dilakukan oleh (Baer dan Frese, 2003) yang menemukan bahwa inovasi dapat dimasukkan untuk menilai kinerja perusahaan. Inovasi akan meningkatkan nilai tambah dari suatu produk serta menciptakan suatu produk baru yang dapat memberikan solusi yang lebih baik bagi pemecahan masalah yang dihadapi konsumen. Sedangkan menurut (Kaufmann, 2001) inovasi juga dapat menciptakan keunggulan bersaing, serta merupakan sarana untuk bertahan hidup dalam menghadapi lingkungan persaingan yang serba tidak pasti. Hubungan inovasi dan kinerja usaha juga dijelaskan oleh (Tidd dan Bessant, 2009) yang menyatakan bahwa tujuan inovasi adalah untuk memanfaatkan peluang dan mengambil keuntungan yang ada sehingga suatu perusahaan dapat terus bertahan. Peluang inovatif merupakan hasil usaha sistematis perusahaan dan hasil dari usaha dengan maksud tertentu untuk menciptakan pengetahuan dan ide-ide baru untuk menerima pengambilan investasi melalui komersialisasi (Chandler, 2002 dalam Casson et al., 2006).

Persaingan usaha memaksa para pelaku usaha yang ada didalamnya untuk memiliki keunggulan dan strategi dalam bersaing agar mampu bertahan dan memenangkan persaingan. Komponen produk (output) yang dihasilkan UKM pun menjadi unsur yang penting untuk diperhatikan oleh pelaku UKM. Mereka yang mampu menyajikan produk yang lebih unggul melalui Orientasi kewirausahaan dan inovasi produk memiliki peluang yang lebih besar untuk menarik minat konsumen. Inovasi tidak bisa dilepaskan dari kehidupan berbisnis karena inovasi merupakan roh atau jiwa dalam sebuah perusahaan untuk berkembang, inovasi dapat berkembang dimana saja dan dilakukan oleh siapa saja, inovasi tidak hanya dilakukan oleh perusahaan besar, melainkan perusahaan kecil pun perlu untuk melakukan inovasi demi keberlangsungan usahanya (Dhewanto,2014:299).

Kota Banjarmasin di Kalimantan Selatan mengandalkan Usaha Kecil dan Menengah (UKM) sebagai salah satu pendorong ekonominya. Pemerintah Kota Banjarmasin baru-baru ini bahkan meluncurkan program Kampung UKM Digital untuk mempromosikan produk UKM Banjarmasin ke kalangan yang lebih luas. Produk usaha kecil dan menengah juga menjadi andalan untuk memikat wisatawan serta pencinta wisata belanja. Budaya.Banjarmasin (2019). 


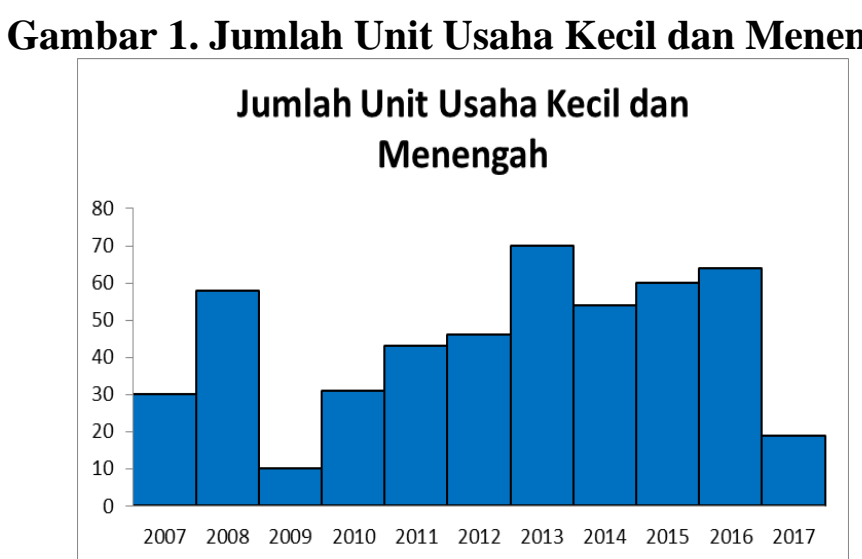

Sumber: BPS Banjarmasin, data diolah (2019)

Dari data di atas dapat dilihat bahwa pada tahun 2007 sampai pada tahun 2017 perkembangan jumlah Unit Usaha Kecil dan Menengah fluktuatif dan relatif mengalami peningkatan. Pada tahun 2007 jumlah Unit Usaha Kecil dan Menengah sebesar 30, kemudian mengalami peningkatan sebesar 58, pada tahun 2009 mengalami penurunan yang signifikan ssebesar 10, kemudian terus mengalami peningkatan signifikan pada tahun 2013 sebesar 70. Pada tahun 2014 mengalami penurunan sebesar sebesar 2014, kemudian mengalami peningkatan sampai tahun 2016 sebesar 64 dan pada 2017 mengalami penurunan sebesar 19.

Pemko Banjarmasin terus bertekad memajukan Usaha Mikro Kecil dan Menengah (UMKM). Hal tersebut ditunjukkan dengan komitmen Walikota Ibnu Sina untuk membentuk 2.500 wirausaha baru semasa kepemimpinannya. Dalam visi menciptakan Wira Usaha Baru (WUB), target yang ingin diraih adalah 500 UMKM per tahun. Dan dalam 3 tahun terakhir yakni dari 2016 hingga 2018 target tersebut telah tercapai. Data terakhir dari Dinas Koperasi Kota Banjarmasin, saat ini jumlah UMKM binaan Pemko Banjarmasin mencapai 2.072 yang kebanyakan adalah para pengrajin sektor kuliner. "Laporan terakhir, dari 2.072 UMKM binaan itu, 50 persennya sudah dianggap mandiri. Jadi kurang lebih 1.000 orang yang sudah kita anggap berhasil dan mandiri. (Kanal.Kalimantan.2019)

Peneliti berkeyakinan bahwa UKM di Banjarmasin ini menjadi hal yang menarik untuk diteliti. Peneliti ingin melihat dan memberikan gambaran mengenai variabel-variabel apa saja yang dapat menjadikan UKM di Banjarmasin mencapai kinerja usahanya. Sehingga dapat dirumuskan sebuah penelitian dengan judul Pengaruh Orientasi Kewirausahaan Dan Inovasi Produk Terhadap Kinerja Usaha Kecil Menengah Dengan Variabel Intervening Keunggulan Bersaing (Studi Pada Ukm Di Banjarmasin)

\section{Rumusan Masalah}

Berdasarkan latar belakang diatas, maka rumusan masalah pada penelitian ini adalah sebagai berikut.

1. Bagaimana pengaruh orientasi kewirausahaan terhadap keunggulan bersaing pada UKM di Banjarmasin? 
2. Bagaimana pengaruh inovasi produk terhadap keunggulan bersaing pada UKM di Banjarmasin?

3. Bagaimana pengaruh orientasi kewirausahaan terhadap kinerja usaha kecil menengah pada UKM di Banjarmasin?

4. Bagaimana pengaruh inovasi produk terhadap kinerja usaha kecil menengah pada UKM di Banjarmasin?

5. Bagaimana pengaruhkeunggulan bersaing terhadap kinerja usaha kecil menengah pada UKM di Banjarmasin?

6. Bagaimana pengaruh orientasi kewirausahaan terhadap kinerja usaha kecil menengah pada UKM di Banjarmasin melalui keunggulan bersaing?

7. Bagaimana pengaruh inovasi produk terhadap kinerja usaha kecil menengah pada UKM di Banjarmasin melalui keunggulan bersaing ?

\section{Tujuan Penelitian}

Berdasarkan rumusan masalah diatas, maka tujuan pada penelitian ini adalah sebagai berikut.

1. Untuk mengetahui dan menganalisa pengaruh orientasi kewirausahaan terhadap keunggulan bersaing pada UKM di Banjarmasin

2. Untuk mengetahui dan menganalisa pengaruh inovasi produk terhadap keunggulan bersaing pada UKM di Banjarmasin

3. Untuk mengetahui dan menganalisa pengaruh orientasi kewirausahaan terhadap kinerja usaha kecil menengah pada UKM di Banjarmasin

4. Untuk mengetahui dan menganalisa pengaruh inovasi produk terhadap kinerja usaha kecil menengah pada UKM di Banjarmasin

5. Untuk mengetahui dan menganalisa pengaruh keunggulan bersaing terhadap kinerja usaha kecil menengah pada UKM di Banjarmasin

6. Untuk mengetahui dan menganalisa pengaruh orientasi kewirausahaan terhadap kinerja usaha kecil menengah pada UKM di Banjarmasin melalui keunggulan bersaing

7. Untuk mengetahui dan menganalisa pengaruh inovasi produk terhadap kinerja usaha kecil menengah pada UKM di Banjarmasin melalui keunggulan bersaing

\section{Kerangka Konseptual}

\section{Gambar 2. Kerangka Konseptual}

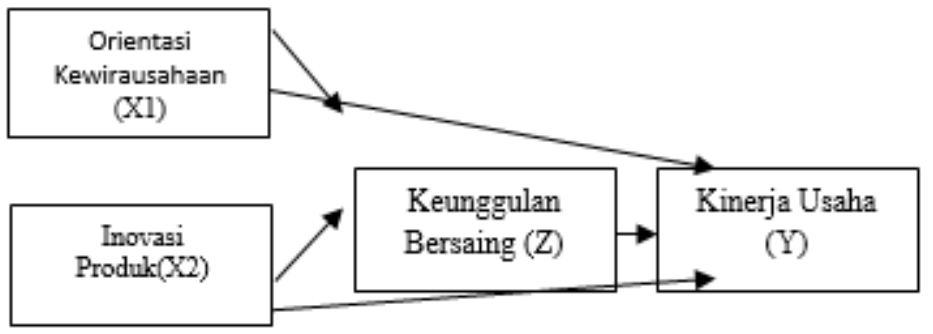

Sumber: Data Primer, diolah (2019) 


\section{KAJIAN PUSTAKA \\ Orientasi Kewirausahaan}

Orientasi kewirausahaan adalah perilaku wirausahawan dalam mengelola usahanya. Orientasi kewirausahaan sebagai strategi benefit perusahaan untuk dapat berkompetensi secara lebih efektif di dalam market place yang sama. Orientasi kewirausahaan mengacu pada proses, praktik, dan pengambilan keputusan yang mendorong ke arah input baru dan mempunyai empat aspek kewirausahaan, yaitu Need for achievement (Keinginan untuk mencapai keberhasilan), Internal locus ofcontrol (keyakinan individu mengenai peristiwa-peristiwa yang berpengaruh dalam kehidupannya akibat tingkah lakunya sehingga dapat di kontrol), self reliance (kemandirian), dan extroversion (keterbukaan terhadap lingkungan). Berikut indikator Orientasi Kewirausahaan :

a. Need for Achievement. Menurut Mc Celland (1987) adalah proses pembelajaran yang stabil yang mana kepuasan akan didapatkan dengan berjuang dan memenuhi level tertinggi untuk dapat menjadi ahli dibidang tertentu.

b. Locus Of Control. Lau (1988, h.52) mengartikan locusof control sebagai kontrol diri yang berkaitan dengan hal-hal yang menyangkut masalah perilaku dari individu yang bersangkutan.

c. Self reliance (kemandirian) Menurut Masrun (1986:8) adalah suatu sikap yang memungkinkan seseorang untuk bertindak bebas, melakukan sesuatu atas dorongan sendiri dan untuk kebutuhannya sendiri tanpa bantuan dari orang lain, maupun berpikir dan bertindak original/kreatif, dan penuh inisiatif, mampu mempengaruhi lingkungan, mempunyai rasa percaya diri dan memperoleh kepuasan dari usahanya

\section{Inovasi Produk}

Inovasi adalah kecenderungan perusahaan untuk menambah produk baru, meniru produk lain (imitasi), dan mengembangkan produk baru (perluasan lini produk).

a. Perluasan Lini Produk. Saladin (2003) Perluasan lini produk adalah usaha yang dilakukan perusahaan untuk menambah produk baru yang memiliki hubungan yang erat karena memiliki fungsi serupa, dijual pada kelompok konsumen yang sama, dipasarkan melalui saluran distribusi yang sama dengan skala harga jual tertentu.

b. Produk Tiruan/Imitasi. Lukas dan Ferrel (2000:240) produk tiruan merupakan produk yang dianggap baru oleh bisnis tetapi familiar dengan pasar. Hariyanto (2011) Imitasi merupakan suatu tindakan sosial seseorang untuk meniru sikap, tindakan, atau tingkah laku orang lain.

c. Produk Baru. Amstrong, G. \& Kotler. P. 1997 Produk baru adalah produk asli, hasil pengembangan produk, modifikasi produk, dan merek baru yang di kembangkan perusahan melalui upaya penelitian dan pengembangannya sendiri. Fandy Tjiptono (1997) mengartikan produk baru dapat meliputi produk orisinil, produk yang di sempurnakan, produk yang di modifikasi, serta merek baru yang di kembangkan melalui usaha riset dan pengembangan 


\section{Keunggulan Bersaing}

Keunggulan bersaing merupakan suatu posisi dimana sebuah perusahaan menguasai sebuah ajang persaingan bisnis (Porter, 1980). Pada penelitian ini indikator penelitian menggunakan teori Bharadwaj et al.,(1993)yaitu :

a. Harga kompetitif

b. Keunikan produk

c. Tidak mudah digantikan

\section{Kinerja Usaha}

Simamora (2001 : 327) mengatakan bahwa kinerja merupakan suatu pencapain persyaratan-persyaratan pekerjaan tertentu yang akhirnya secara langsung dapat tercermin dari output yang dihasilkan baik jumlah maupun kualitasnya. Menurut UU no.9 tahun 1995. Tentang usaha kecil dan menengah, yang dimaksud dengan usaha kecil adalah kegiatan ekonomi rakyat yang memiliki kekayaan bersih paling banyak Rp. 200 juta, tidak termasuk tanah dan bangunan tempat usaha atau yang memiliki hasil penjualn tahunan paling banyak Rp. 1 milyar dan di miliki oleh warga negara indonesia (WNI). Indikator Kinerja Usaha MikroSiregar (2016) yaitu kuantitatif dan kualitatif.

\section{METODE PENELITIAN \\ Jenis Penelitian}

Jenis penelitian ini termasuk dalam jenis penelitian yang bersifat eksplanasi ilmu dapat digolongkan pada jenis penelitian kausalitas yaitu penelitian yang ingin mencari penjelasan dalam bentuk hubungan sebab akibat (cause- effect) antar beberapa konsep atau beberapa variable atau beberapa strategi yang dikembangkan dalam manajemen dan diarahkan untuk menggambarkan adanya sebab akibat antara beberapa situasi yang digambarkan dalam variable, dan atas dasar itu ditariklah sebuah kesimpulan umum (Ferdinand, 2014).

\section{Tempat, Waktu dan Subjek Penelitian}

Adapun waktu penelitian di lakukan pada bulan Januari sampai dengan bulan Maret 2020 dengan melakukan Tahap Persiapan, Tahap Pengumpulan Data di Lapangan dan juga Tahap Pengolahan Data

Moleong (2010: 132) mendeskripsikan subjek penelitian sebagai informan, yang artinya orang pada latar penelitian yang dimanfaatkan untuk memberikan informasi tentang situasi dan kondisi latar penelitian. Subjek pada penelitian ini adalah pelaku UKM yang ada di Banjarmasin dan memiliki produk tersebar di ritel modern.

\section{Teknik Pengumpulan Data}

Teknik pengumpulan data yang digunakan dalam penelitian ini adalah melalui kuesioner, wawancara dan studi pustaka.

1. Kuesioner

Kuesioner merupakan daftar pertanyaan yang digunakan sipeneliti untuk memperoleh data secara langsung dari sumber melalui proses komunikasi atau 
dengan mengajukan pertanyaan. Pengambilan data melalui kuesioner dilakukan dengan memberi daftar pertanyaan pada karyawan yang menjadi sample penelitian, untuk mendapatkan data primer serta memperoleh informasi tertulis jari responden sebagai obyek penelitian. Menurut Jonathan, (2012:52) dalam penyusunan kuesioner ada beberapa pertimbangan yang harus dilakukan, yaitu :

a. Sejauh mana suatu pertanyaan dapat mempengaruhi responden menunjukkan sikap yang positif terhadap hal - hal yang ditanyakan.

b. Sejauh mana suatu pertanyaan dapat mempengaruhi responden agar dengan suka rela membantu peneliti dalam menemukan hal - hal yang akan dicari oleh peneliti.

c. Sampai sejauh mana suatu pertanyaan menggali informasi yang responden sendiri tidak meyakini kebenarannya.

d. Pertanyaan - pertanyaan yang disampaikan kepada responden mudah dipahami dan dijawab dengan benar.

e. Apakah pertanyaan yang dibuat memang diperlukan.

2. Wawancara

Wawancara adalah metode yang digunakan untuk memperoleh informasi secara langsung, mendalam, tidak terstruktur, dan individual, ketika seorang responden ditanyai pewawancara guna mengungkapkan perasaan, motivasi, sikap, atau keyakinannyaterhadap suatu topik SDM (Istijanto, 2010:44). Informasi yang diperoleh bisa memperjelas atau mendukung jawaban yang disampaikan melalui kuesioner.

3. Studi pustaka

Suatu metode pengumpulan data dengan menggunakan buku - buku dan mempelajari literatur-literatur yang berhubungan dengan penelitian ini.

\section{Teknik Analisa Data}

Penelitian ini menggunakan metode analisa data kuantitatif, teknik analisis yang Dalam penelitian ini, metode analisis data yang digunakan adalah Partial Least Square (PLS) yaitu teknik prediktif yang merupakan alternative untuk regresi kuadrat terkecil biasa (Ordinary Least Square/PLS) korelasi kanonik, atau permodelan persamaan Structural Equatuion Modeling(Sarwono \& Narimawati, 2015, pp. 1-2). Alasan pemilihan menggunakan metode $P L S$ ini adalah disesuaikan dengan tujuan penelitian ini yaitu selain untuk menguji pengaruh variabel independen/ eksogen terhadap variable dependen/ eksogen juga ada pengujian peran mediasi suatu variabel intervening yang pengujian- pengujian tersebut dapat dilakukan dengan menggunakan metode $P L S$.

\section{HASIL PENELITIAN DAN PEMBAHASAN \\ Hasil Penelitian \\ Skema Model Partial Least Square (PLS)}

Pada penelitian ini, pengujian hipotesis menggunakan teknik analisis Partial Least Square (PLS) dengan program smartPLS. Berikut ini adalah sekema model program PLS yang diujikan: 


\section{Gambar 3. Hasil PLS Algoritma}

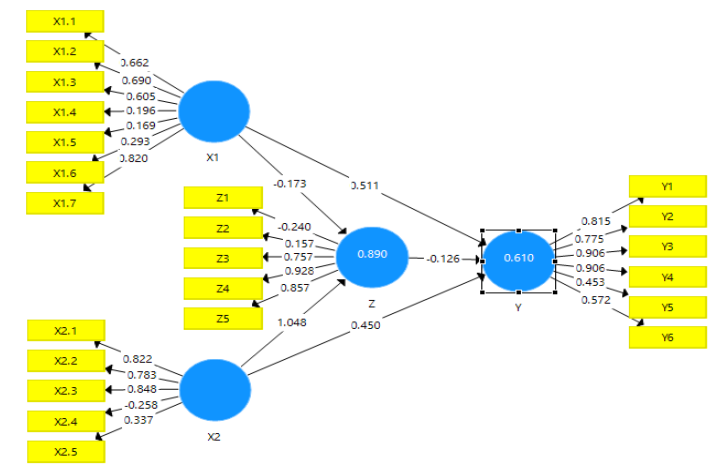

Sumber : Data Primer, diolah (2019)

\section{Evaluasi Outer Model}

Uji prasyarat model 1 yang digunakan sebagaimana yang digunakan pada model 1. Berikut adalah hasil uji prasyarat model :

Tabel 3. Hasil Uji Prasyarat model 1

\begin{tabular}{|c|c|c|c|c|}
\hline & Cronbach's Al... & rho_A & Reliabilitas Ko... & Rata-rata Varia... \\
\hline $\mathrm{X} 1$ & 0.739 & 0.650 & 0.707 & 0.301 \\
\hline $\mathrm{X} 2$ & 0.577 & 0.660 & 0.695 & 0.438 \\
\hline Y & 0.839 & 0.882 & 0.884 & 0.573 \\
\hline z & 0.400 & 0.824 & 0.687 & 0.450 \\
\hline
\end{tabular}

Sumber : Data Primer Diolah, 2019

Berdasarkan tabel diatas menunjukan nilai AVE pada variabel kinerja usaha memiliki nilai AVE lebih besar dari 0,5 jadi tidak diperlukan perbaikan model dengan mengeliminasi indikator. Pada variabel orientasi kewirausahaan, inovasi produk dan keunggulan bersaing kurang dari 0,5 jadi diperlukan perbaikan model dengan mengeliminasi indikator pada orientasi kewirausahaan, inovasi produk dan keunggulan bersaing yang memiliki nilai outer loading terendah.

Adapun hasil terendah dan yang tereleminasi adalah Variabel orientasi kewirausahaanpada item pertanyaan X1.3, X1.4, X1.5, X1.6. Variabel inovasi produk pada item pertanyaan X2.4. Pada variabel keunggulan bersaing hasil terendah dan yang tereleminasi adalah pada item pertanyaan Z1. Berikut hasil eliminasi hasil uji prasyarat 1.

Gambar 4. Hasil PLS Algoritma

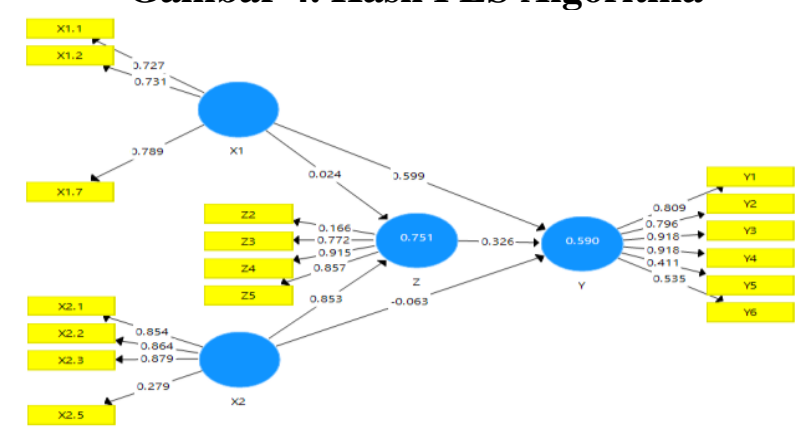

Sumber : Data Primer, diolah (2019) 


\section{a. Discriminant Validity}

Pengujian discriminant validity dilakukan untuk membuktikan apakah indikator pada suatu konstruk akan mempunyai loading factor terbesar pada konstruk yang dibentuknya dari pada loading factor dengan konstruk yang lain. Jika korelasi antara variabel laten dengan setiap indikatornya (variabel manifes) lebih besar daripada korelasi dengan variabel laten lainnya, maka variabel laten tersebut dapat dikatakan memprediksi indikatornya lebih baik daripada variabel laten lainnya. Jika nilai akar kuadrat AVE setiap konstruk lebih besar daripada nilai korelasi antara konstruk dengan konstruk lainnya dalam model, maka dikatakan memiliki nilai discriminant validity yang baik dan untuk nilai AVE yang diharapkan adalah lebih besar dari 0,5 (> 0.5).

Tabel 4. Hasil Uji Avarage Variance Extracted (AVE)

\begin{tabular}{|c|c|}
\hline Konstruk & AVE \\
\hline Orientasi Kewirausahaan & 0,562 \\
\hline Orientasi Kewirausahaan, Inovasi Produk & 0,581 \\
\hline Keunggulan Bersaiang & 0,549 \\
\hline Kinerja Usaha & 0,572 \\
\hline
\end{tabular}

Sumber : Hasil Penelitian, diolah (2019)

Berdasarkan sajian data dalam tabel atas, diketahui bahwa nilai AVE semua variabel $>0,5$ lebih besar dari 0,5. Dengan demikian dapat dinyatakan bahwa setiap variabel telah memiliki discriminant validity yang baik

\section{b. Composite Reliability}

Composite Reliability adalah indeks yang menunjukkan sejauh mana suatu alat pengukur dapat dipercaya untuk diandalkan. Data yang memiliki composite reliability > 0.7 mempunyai reliabilitas yang tinggi. Composite reliability blok indikator yang mengukur suatu konstruk dapat dievaluasi dengan dua macam ukuran yaitu internal consistency dan Cronbach's Alpha

Tabel 5. Hasil Uji Composite Reliability

\begin{tabular}{|c|c|}
\hline Konstruk & Compisite Reliabilty \\
\hline Orientasi Kewirausahaan & 0,794 \\
\hline Orientasi Kewirausahaan, Inovasi Produk & 0,832 \\
\hline Keunggulan Bersaiang & 0,803 \\
\hline Kinerja Usaha & 0,882 \\
\hline
\end{tabular}

Sumber : Hasil Penelitian, diolah (2019)

Berdasarkan sajian data pada tabel di atas, dapat diketahui bahwa nilai composite reliability semua variabel penelitian $>0,7$. Hasil ini menunjukkan bahwa masing-masing variabel telah memenuhi composite reliability sehingga dapat disimpulkan bahwa keseluruhan variabel memiliki tingkat reliabilitas yang tinggi 


\section{Uji Hipotesis}

Hasil output uji hipotesis dengan smart PLS baik hipotesis pengaruh langsung maupun tidak langsung dapat dilihat pada tabel dibawah ini.

a. Pengaruh Langsung

Tabel 6. Hasil Uji Pengaruh Langsung

\begin{tabular}{|c|c|c|c|c|c|}
\hline & Sampel ASli (0) & Rata-rata Samm.". & Standar Devisisi (STDEV) & TStatisitik (O/STDEV |) & PValues \\
\hline 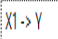 & 0.507 & 0.519 & 0.471 & 1,289 & 0.198 \\
\hline$X 1 \cdot>I$ & 0.024 & 0.073 & 0.341 & 0.071 & 0.943 \\
\hline$x 2 \cdot 3$ & 0.215 & 0,324 & 0,482 & 0.46 & 0.656 \\
\hline$x 2 \cdot>I$ & 0.553 & 0.836 & 0,316 & 2702 & 0.007 \\
\hline$Z \bullet Y$ & 0.326 & 0.339 & 0.759 & 0.430 & 0.667 \\
\hline
\end{tabular}

Sumber : Hasil Penelitian, diolah (2019)

1) Diketahui pengaruh orientasi kewirausahaan terhadap keunggulan bersaing pada UKM di BanjarmasinX1 -> Z T tabel 1,77093 lebih besar dari T-statistik 0,071, selain itu memiliki nilai $\mathrm{P}$ Value 0,943 lebih besar dari 0,05 dengan demikianorientasi kewirausahaan tidak berpengaruh secara langsung keunggulan bersaing pada UKM di Banjarmasin.

2) Diketahui pengaruh inovasi produk terhadap keunggulan bersaing pada UKM di BanjarmasinX2 -> Z T tabel 1,77093 lebih kecil dari T-statistik 2,702, selain itu memiliki nilai $\mathrm{P}$ Value 0,007 lebih kecil dari 0,05 dengan demikianinovasi produk berpengaruh secara langsung keunggulan bersaing pada UKM di Banjarmasin

3) Diketahui pengaruh orientasi kewirausahaan terhadap kinerja usaha pada UKM di BanjarmasinX1 -> Y T tabel 1,77093 lebih besar dari T-statistik 1,289, selain itu memiliki nilai P Value 0,198 lebih besar dari 0,05 dengan demikian orientasi kewirausahaan tidak berpengaruh secara langsung kinerja usaha pada UKM di Banjarmasin.

4) Diketahui pengaruh inovasi produkterhadap kinerja usaha pada UKM di BanjarmasinX2 -> Y T tabel 1,77093 lebih besar dari T-statistik 0,446, selain itu memiliki nilai $\mathrm{P}$ Value 0,656 lebih besar dari 0,05 dengan demikianinovasi produk tidak berpengaruh secara langsung kinerja usaha pada UKM di Banjarmasin.

b. Pengaruh Tidak Langsung

Tabel 7. Hasil Uji Pengaruh Tidak Langsung

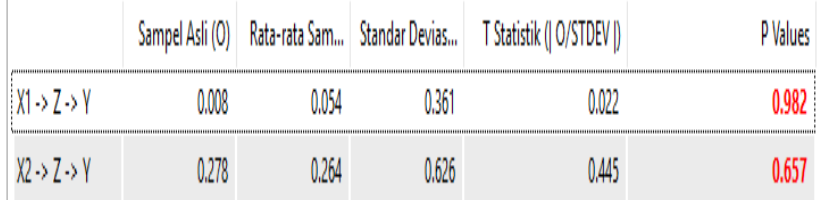

Sumber : Hasil Penelitian, diolah (2019)

1) Diketahui pengaruh tidak langsung orientasi kewirausahaan terhadap kinerja usahamelalui keunggulan bersaing pada UKM di Banjarmasin X1 -> Z-> Y T tabel 1,77093 lebih besar dari T-statistik 0,022, selain itu memiliki nilai $\mathrm{P}$ Value 0,982 lebih besar dari 0,05 dengan demikianorientasi kewirausahaan tidak 
berpengaruh secara tidak langsung terhadap terhadap kinerja usaha melalui keunggulan bersaing pada UKM di Banjarmasin.

2) Diketahui pengaruh tidak langsung inovasi produk terhadap kinerja usaha melalui keunggulan bersaing pada UKM di Banjarmasin X2 -> Z-> Y T tabel 1,77093 lebih besar dari T-statistik 0,445, selain itu memiliki nilai P Value 0,657 lebih besar dari 0,05 dengan demikianinovasi produk tidak berpengaruh secara tidak langsung terhadap terhadap kinerja usaha melalui keunggulan bersaing pada UKM di Banjarmasin.

\section{Pembahasan}

\section{Pengaruh Orientasi Kewirausahaan Terhadap Keunggulan Bersaing Pada UKM di Banjarmasin}

Berdasarkan hasil pengujian Orientasi Kewirausahaan tidak berpengaruh secara langsung terhadap Keunggulan Bersaing Pada UKM di Banjarmasin, hasil tersebut membuktikan meningkatnya Orientasi Kewirausahaan tidak serta merta mampu meningkatkan Keunggulan Bersaing Pada UKM Di Banjarmasin.

Hal ini disebabkan, Orientasi Kewirausahaan yang terjadi pada UKM di Banjarmasinterbukti belum tinggi, dan Orientasi Kewirausahaan masih cenderung naik turun. Tingginya hambatan, rintangan, dan tantangan belum mampu meningkatkan keuangggulan bersaing pada Pada UKM di Banjarmasin. Hambatan risiko merupakan faktor kunci jika memiliki jiwa wirausaha yang baik kemudian memiliki Orientasi Kewirausahaan yang tinggi. Fungsi utama dari tingginya orientasi kewirausahaan adalah bagaimana melibatkan pengukuran risiko dan pengambilan risiko secara optimal untuk menghadapi persaingan yang ketat.

\section{Pengaruh Inovasi Produk Terhadap Keunggulan Bersaing Pada UKM di Banjarmasin}

Berdasarkan hasil pengujian Inovasi Produk berpengaruh secara langsung terhadap Keunggulan Bersaing Pada UKM di Banjarmasin, hasil tersebut membuktikan meningkatnya Inovasi Produk serta merta mampu meningkatkan Keunggulan Bersaing Pada UKM di Banjarmasin.

Hal ini menunjukkan bahwa UKM di Banjarmasin telah melaksanakan keempat dimensi dari inovasi produk yang meliputi produk, Proses dan Organisasi yang baik. UKM di Banjarmasin dapat melakukan berbagai inovasi dengan membuat berbagai macam desain produk, dan menambah nilai guna suatu barang. Inovasi produk juga merupakan salah satu dampak dari perubahan teknologi yang cepat. Kemajuan teknologi yang cepat dan tingginya tingkat persaingan menuntut setiap UKM di Banjarmasin untuk terus menerus melakukan inovasi produk yang pada akhirnya akan meningkatkan keunggulan bersaing tersebut. UKM di Banjarmasin menciptakan inovasi produk dengan berbagai macam desain produk, sehingga meningkatkan alternatif pilihan, meningkatkan manfaat atau nilai yang diterima oleh pelanggan, sehingga inovasi produk adalah salah satu cara UKM di Banjarmasin dalam mempertahankan keunggulan bersaing 


\section{Pengaruh Orientasi Kewirausahaan Terhadap Kinerja Usaha Kecil Menengah Pada UKM di Banjarmasin}

Berdasarkan hasil pengujian Orientasi Kewirausahaan tidak berpengaruh secara langsung terhadap Kinerja Usaha Kecil Menengah Pada UKM di Banjarmasin, hasil tersebut membuktikan meningkatnya Orientasi Kewirausahaan tidak serta merta mampu meningkatkan Kinerja Usaha Kecil Menengah Pada UKM Di Banjarmasin.

Hal ini disebabkan, Orientasi Kewirausahaan yang terjadi pada UKM di Banjarmasin terbukti belum tinggi, dan Orientasi Kewirausahaan masih cenderung naik turun. Tingginya Need for Achievement proses pembelajaran yang mana didapatkan dengan berjuang, Internal locus of Control kontrol diri yang berkaitan dengan permasalahan, Self Relience sikap untuk bertindak bebas, melakukan sesuatu atas dorongan sendiridan Extroversion memiliki interaksi sosial yang tinggi dan juga aktif belum mampu meningkatkan Kinerja Usaha Kecil Menengah Pada UKM di Banjarmasin.

\section{Pengaruh Inovasi Produk Terhadap Kinerja Usaha Kecil Menengah pada UKM di Banjarmasin}

Berdasarkan hasil pengujian Inovasi Produktidak berpengaruh secara langsung terhadap Kinerja Usaha Kecil Menenga Pada UKM di Banjarmasin, hasil tersebut membuktikan meningkatnya Inovasi Produk tidak serta merta mampu meningkatkan Kinerja Usaha Kecil Menengah Pada UKM Di Banjarmasin.

Hal ini disebabkan,Inovasi Produkpada UKM di Banjarmasin yang diukur dengan mampu mengasilkan produk yang berkualitas, mampu mengasilkan produk sesuai keinginan konsumen, selalu memperhatikan efisiensi proses, konsistensi dan ketepatan waktu, Karyawan dapat berpikir kritis dalam melakukan evaluasi dan Pihak manajemen mampu menciptakan atau mengembangkan ide-ide baru belum optimal dijalankan, sehingga blum mampu memberikan dampak secara langsung salah satunya Peningkatan penjualan, Pertumbuhan keuntungan yang berkelanjutan dan Kedisiplinan yang ada pada tenaga kerja untuk kemajuan kinerja usaha.

\section{Pengaruh Keunggulan Bersaing Terhadap Kinerja Usaha Kecil Menengah Pada UKM di Banjarmasin}

Berdasarkan hasil pengujian Keunggulan Bersaing tidak berpengaruh secara langsung terhadap Kinerja Usaha Kecil Menengah Pada UKM di Banjarmasin, hasil tersebut membuktikan meningkatnya Keunggulan Bersaing tidak serta merta mampu meningkatkan Kinerja Usaha Kecil Menengah Pada UKM di Banjarmasin. Hal ini diduga ada kaitannya dengan mentalitas bersaing para pelaku UKM yang rendah dikarenakan oleh faktor persaudaraan, dan rasa sosial yang tinggi sesama pelaku UKM sehingga dinamika dan perkembangan usaha relatif sama

\section{Pengaruh Orientasi Kewirausahaan Terhadap Kinerja Usaha Kecil Menengah Pada UKM di Banjarmasin Melalui Keunggulan Bersaing}

Berdasarkan hasil pengujian Orientasi Kewirausahaan tidak berpengaruh secara tidak langsung terhadap Kinerja Usaha Kecil Menengah Pada UKM di Banjarmasin Melalui Keunggulan Bersaing, hasil tersebut membuktikan meningkatnya Orientasi 
Kewirausahaan dan juga meningkatnya keunggulan bersaing tidak serta merta mampu meningkatkan Kinerja Usaha Kecil Menengah Pada UKM di Banjarmasin Melalui Keunggulan Bersaing.

Meningkatkan kinerja bisnis, para pelaku UKM di Banjarmasin tidak cukup hanya dengan kerja keras, tetapi perlu menerapkan pula prinsip kerja cerdas. Hasil penlitian tersebut membuktikan para pelaku UKM di Banjarmasin saat ini dalam Orientasi Kewirausahaan belum memiliki keberanian menghadapi tantangan dan mengambil resiko.

\section{Pengaruh Inovasi Produk Terhadap Kinerja Usaha Kecil Menengah Pada UKM di Banjarmasin Melalui Keunggulan Bersaing}

Berdasarkan hasil pengujian Inovasi Produk tidak berpengaruh secara tidak langsung terhadap Kinerja Usaha Kecil Menengah Pada UKM di Banjarmasin Melalui Keunggulan Bersaing, hasil tersebut membuktikan meningkatnya Inovasi Produk dan juga meningkatnya keunggulan bersaing tidak serta merta mampu meningkatkan Kinerja Usaha Kecil Menengah Pada UKM di Banjarmasin Melalui Keunggulan Bersaing.

Penelitian ini membuktikan dalam mengembangkan usaha tidak hanya terfokuskan pada inovasi produk saja, tapi juga perlu adanya kreativitas dalam cara cara memasarkan produknya yaitu dengan memanfaatkan sarana teknologi informasi sehingga Kinerja Usaha Kecil Menengah pada UKM di Banjarmasindan juga Keunggulan Bersaing akan meningkat

\section{KESIMPULAN DAN SARAN \\ Kesimpulan}

Berdasarkan hasil pengujian Orientasi Kewirausahaan tidak berpengaruh secara langsung terhadap Keunggulan Bersaing Pada UKM Di Banjarmasin. Inovasi Produk berpengaruh secara langsung terhadap Keunggulan Bersaing Pada UKM di Banjarmasin, hasil tersebut membuktikan meningkatnya Inovasi Produk serta merta mampu meningkatkan Keunggulan Bersaing Pada UKM di Banjarmasin. Orientasi Kewirausahaan tidak berpengaruh secara langsung terhadap Kinerja Usaha Kecil Menengah Pada UKM di Banjarmasin. Inovasi Produk tidak berpengaruh secara langsung terhadap Kinerja Usaha Kecil Menengah Pada UKM di Banjarmasin. Keunggulan Bersaing tidak berpengaruh secara langsung terhadap Kinerja Usaha Kecil Menengah Pada UKM di Banjarmasin. Orientasi Kewirausahaan tidak berpengaruh secara tidak langsung terhadap Kinerja Usaha Kecil Menengah Pada UKM di Banjarmasin Melalui Keunggulan Bersaing. Inovasi Produk tidak berpengaruh secara tidak langsung terhadap Kinerja Usaha Kecil Menengah Pada UKM di Banjarmasin Melalui Keunggulan Bersaing.

\section{Saran}

Bagi pemilik usaha orientasi kewirausahaan merupakan variabel yang tidak berpengaruh signifikan dan belum dapat meningkatkan Kinerja Usaha dan Keunggulan Bersaing Pada UKM Di Banjarmasin. Akan tetapi teori menjelaskan bahwa indicator pada orientasi kewirausahaan mampu meningkatkan kinerja usaha, oleh karena itu 
pemilik usaha harus senantiasa bersikap daya juang yang tinggi dalam berusaha meraih prestasi bisnis (need for achievement), percaya terhadap kemampuan diri (internal locus of control), mandiri (self reliance) serta sikap yang terbuka terhadap lingkungan (extroversion) perlu lebih di tingkatkan kembali. Dan tidak lupa pula untuk melakukan inovasi, karena inovasi juga merupakan variabel yang dapat meningkatkan Keunggulan Bersaing Pada UKM di Banjarmasin.

\section{DAFTAR PUSTAKA}

Amstrong, G. \& Kotler. P. 1997. Prinsip-prinsip pemasaran. Cetakan pertama. Jakarta: Erlangga

Anderson, M., Kaufman, J., Simon, T.R, Barrios,L., Paulozzi, L., Ryan, G. 2001. School-associated violent deaths study group.. Journal of the American Medical Association, 286, 2695-270

Almeida, L. S., Prieto, L. P., Ferrando, M., Oliveira, E., Ferrándiz, C. 2010. Torrance Test of Creative Thinking: The question of its construct validity. Elsevier, Thinking Skills and Creativity, 53-58

Baer, Markus dan Michael Frese, 2003, Innovation Is Not Enough: Climates For Initiative And Psychological Safety, Process Innovations, And Firm Performance, J. Organiz. Behav. 24, 45-68

Bharadwaj, Sundar G., Varadarajan, P Rajan, dan Fahy, John, 1993, "Sustainable Competitive Advantage in Service Industries: A Conceptual Model and Research Proposition”, Journal of Marketing, October, Vol.57, Iss. 4, pg. 83, 17 pgs

Bilson, Simamora. 2001. Memenangkan Pasar dengan Pemasaran Efektif dan Profitabel, Edisi Pertama, Jakarta, PT. Gramedia Pustaka Utama

BPS Banjarmasin, 2018

Casson M, Yeung B, Basu A, Wadeson N. 2006. The Oxford Handbook of Entrepreneurship. New York : Oxford University Press Inc

Dhewanto, W. 2014. Manajemen Inovasi : Peluang Sukses Menghadapi Perubahan. Yogyakarta: CV.ANDI OFFSET

Fandy Tjiptono, 1997, Strategi Pemasaran, Edisi 1, Penerbit Andi, Yogyakarta

Ferdinand, Augusty. 2014. Metode Penelitian Manajemen. BP Universitas Diponegoro. Semarang

Kanaidi., dan Kurniawan, Ari. 2014. Analisis Customer Relationship Management

Lau, Geok Then and Sook Han Lee. 1988. "Consumers Trust in a Brand and the Link to Brand Loyalty". Journal of Market Focused Management

Lukas, B.A. and Ferrel, O.C. 2000. "The Effect of Market Orientation on Product Innovation”. Journal of The Academy Marketing Science. No.2 Vol.28. p.239247

Masrun, dkk. 1986. Studi Mengenai Kemandirian Pada Penduduk di Tiga Suku (Jawa, Batak, Bugis). Laporan Penelitian. Yogyakarta: Universitas Gajah Mada

McClelland, D.C. 1987. Human Motivation. New York : Cambridge University Press

Moleong, Lexy J. 2010. Metodologi penelitian kualitatif. Bandung: Remaja Rosdakarya.

Porter, M.E. 1980, Competitive Strategy, Techiques for Analyzing Industries and Competitor, Macmillan Publishing Company, New York 
Reni Shinta Dewi 2014, Pengaruh Faktor Modal Psikologis, Karakteristik Entrepreneur, Inovasi, Manajemen Sumber Daya Manusia dan Karakteristik UKM Terhadap Perkembangan Usaha Pedagang

Rauch, A dan Frese, M. 2009. A Meta-Analysis on the Relationship between Business Owners' Personality Traits, Business Creation, and Success. European Journal of Work and Organizational Psychology

Rita Indah Mustikowati, 2014, Orientasi Kewirausahaan, Inovasi, dan Strategi Bisnis untuk Meningkatkan Kinerja Perusahaan (Studi Pada UKM Sentra Kabupaten Malang)

Sarwono, Jonathan \& Narimawati, Umi. 2015. Membuat Skripsi, Tesis, dan Disertasi Partial Least Square SEM (PLS-SEM). Yogyakarta: C.V ANDI OFFSET

Saladin, Djaslim, 2003, "Intisari Pemasaran dan Unsur-unsur Pemasaran”, Cetakan Ketiga, Bandung : Linda Karya

Siregar, 2016, Pengaruh Entrepreneurial Networking dan Karakteristik Wirausaha terhadap Kinerja Usaha Mikro (Studi pada usaha mikro kawasan Kecamatan Medan Perjuangan dan Medan Barat)

Siswanto. 2011. Pengantar Manajemen. Jakarta : Bumi Aksara

Tidd, Joe and Bessant. 2009, "Managing Innovation”, 4th edition, John Wiley \& Sons Ltd., England

Undang-Undang No.9 tahun 1995. Tentang usaha kecil dan menengah 